\title{
釧路気象台における強震動と地盤・構造物の振動特性 STRONG GROUND MOTIONS AT KUSHIRO OBSERVATORY AND VIBRATION CHARACTERISTICS OF GROUND AND STRUCTURES
}

\author{
太田 外氣晴* \\ Tokiharu OHTA
}

\begin{abstract}
This paper describes the microtremor measurements of ground, seismograph foundation and two storied building at Kushiro observatory. Also, non-linear characteristics of strong ground motion during the 1993 Kushiro-oki earthquake are analyzed. The results are summarized as follows:

1) Natural frequency of seismograph foundation is $10 \mathrm{~Hz}$ for transverse and longtudinal directions. Rocking motion of the foundation is appeared.

2) Natural frequency of the west side building is $4 \mathrm{~Hz}$ for transverse and longtudinal directions.

3) Peak frei-lency of low level earthquake motion is $10 \mathrm{~Hz}$. But, the main-shock, peak frequencies decrease and the spectral revel are not so high because of inc reased damping characteristics of soils around the foundation.

4) Many previous studies are reviewed and discussed, then, representative predomin ant frequency of ground and structures are pointed out.
\end{abstract}

Keymords. microtremor, strong motion, foundation, building, rocking motion, predominant frequency

常時微動、強震動、基礎、建物、ロッキング振動、卓越振動数

\section{§1 まえがき}

1993年1月15日の釧路沖地震（地震規模M7.8）におい て、釧路気象台の87型地震計で919Gal, SMAC-MD型強震計 （建設省建築研究所）で711Galという大加速度が記録さ れた。これらは加速度値の割に小被害であったことと、 1962年広尾沖地震(M7)における大加速度記録の経緯とも 関連して多大の関心を呼んだ。

このため、多くの研究者による測定や各種の研究が行 われてきた。地震動や構造物も含めた研究として、例え ば文献1)の地盤、地震計用基礎、電波塔などの常時微動 測定、文献2)の気象台地表の強震記録、文献3)の地震計 基礎と建物の常時微動測定、文献4)の気象台における強 震動発生に関わる分析、文献5)の気象台敷地内の常時微 動測定など、E S Gグループによる文献6)に代表される 多数の研究者による気象台敷地の詳細な常時微動測定、 文献7） 9）の気象台建物と地震計用基礎、敷地の常時微 動測定など、文献10）～12）の気象台建物と地震計基礎 の振動特性に関わる研究、文献13)の気象台地盤の弾塑
牲応答解析などがある。これらのうち、初期のものは記 録の分析や測定が主であり、次の段階で議論がなされた が、主たる論点として次の事項があげられる。

i） 87 型用地震計基礎のピーク振動数 $\mathrm{f} \mathrm{p}=10 \mathrm{~Hz}$ は基脴固 有のもの たもの71121かの疑問、

i i ）建物一地震計基礎一地盤の相互作用解析において、 地震計基礎に対する建物の影響をどう評価するかの 問題点 ${ }^{71-121}$ 、

iii) $2 \mathrm{H} z$ zの成分はレーダー塔の影響を受けたものか否 か1121。

これらについては1994年12月に開催された1993年釧路 沖地震に関する総合シンポジュウム（日本建築学会）に おいてかなり明確化された。しかし、議論の範囲は広く、 内容的な掘り下げにも限界があった。即ち、この地震の 地震動などに関する研究は過去に例を見ないほど多く、 それらの内容を把握して相互に矛盾のない特性評価を行 うことは容易でないからである。 
また、容易に明確な結論に到達しない理由は、大加速 度による非線形応答の議論であることと、ある程度のバ ラツキを覚悟せざるを得ない常時微動に多く依存してい

ることにもよる。

そこで、本論では、筆者らが行ってきた87型地震計基 礎と表層地盤の振動特性、及び構造物の振動特性に関す る追加分析と研究のまとめを行うと共に、関連する諸研 究との比較検討を行い、これらを総合的に分析し、統一 的に判断できる点と残る問題点を明らかにしようとする ものである。

\section{§ 2 湘定・観測の位置}

1993年 1月15日の釧路沖地震本震の約 2 か月後と、19 94年 8 月に常時微動（MT）の測定を実施した。これら の測定位置を図 1 に示す。気象领釗路地方気象台（以下 ではJ M 0人記す) での測定位置を図 2 に示す。MTの測 定は87型地震計が設置されていたJ M 0のRC造の独立基礎 上、2 階建ての庁舎の屋上、敷地の地表面、及び庁舎北 側の崖のすぐ下に位置する『つたや旅館 (TYR)』である。 気象台庁舎は建物中奥近くにエキスパンション・ジョイ ントを有する。

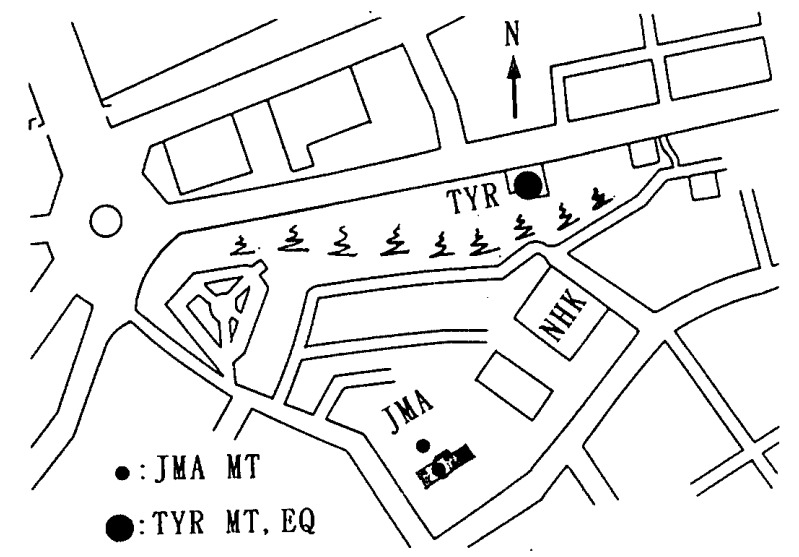

図1 釧路気象台とその周辺における測定・観測位置
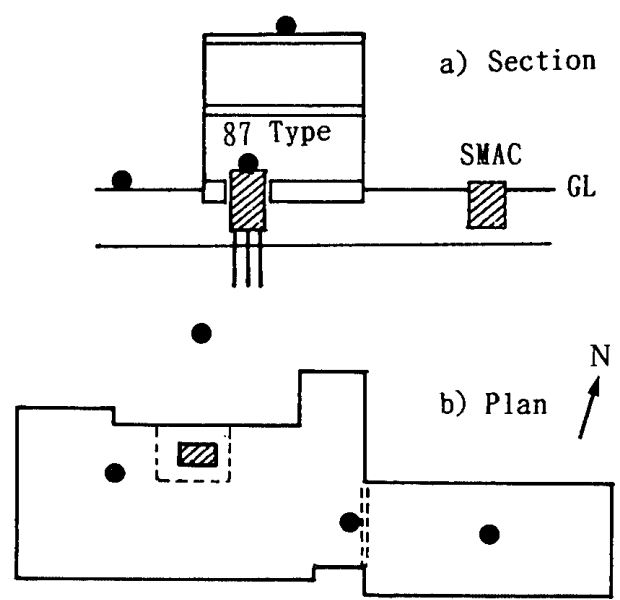

図2 釗路気象台仃舎の概要と測定点
図 3 はT Y Rの建物概要と主な測定点である。この建物 は鉄骨造の 3 階建である。図 4 は地質断面 '小に両地点 の位置を示したもので、T Y Rは古第三紀層の掘削面に位 置し、市内では最も地盤の堅い地点の一つである。J M 0 のGLは標高 $31.3 \mathrm{~m}$, TYRは標高2.7mである。

なお、TYR南側の崖側の地表と建物内で多点のM Tを 測定したが、その結果、建物の影響は微小である事を確 認している。

\section{§3 地震計基礎の振動特性}

\subsection{7型地震計基礎の振動}

$\mathrm{J}$ M 0の地震計用基礎と庁舎の建物屋上、及び地表につ いてMTの測定をさせて頂いた。その屋上における測定 点は地震計室のある西棟の東西で 2 点、東棟中央の 1 点 である。この基礎は長さが $2.6 \mathrm{~m}$, 幅が $1.82 \mathrm{~m}$, 高さが 2.78 mで、1.64mが地中に埋め込まれている。また、その重 量は約30tonである。

J M 0の地震計用基礎上の測定を実施した時、建物は外 装などの工事中であったため、工事に伴う物の落下によ ると思われる自由振動が発生する例が見られた。そこで、 両手で基礎の頂部を加振する自由振動実験をさせて頂い
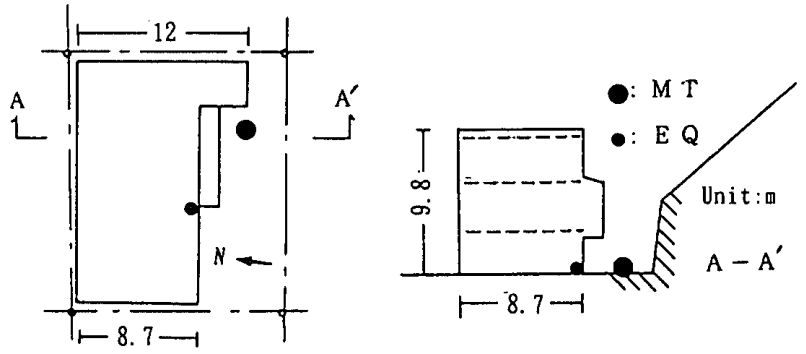

図3 崖下のつたや旅館 (TYR) と測定・観測点

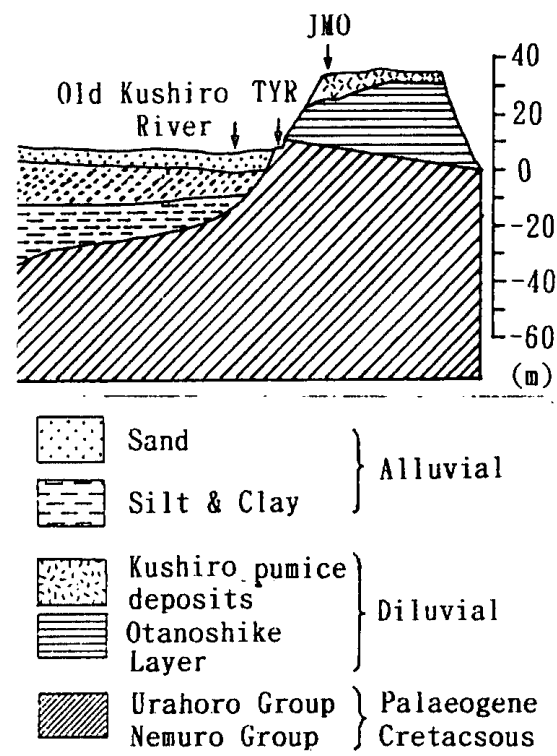

図4 釧路市の地質断面と測定・観測点 
た。それらの短辺方向の加速度波形を図 $5 ， 6$ に示す。 これらは共に明瞭な自由振動が発生したと認められるの で、基礎の固有振動数 $f \mathrm{p}$ 読み取った。短辺方向の値は $\mathrm{fp}=10 \mathrm{~Hz}$ で (図7)、、隇衰定数は $\mathrm{h}=0.045$ と得られた。 長辺方向と上下方向についても測定し、長辺の $\mathrm{fp} か ゙ 10 \mathrm{~Hz}$ , hが0.07, 上下のfpが15Hz.上得られた。これらのfpと $\mathrm{h}$ をまとめて表 1 に示す。

\section{2 地表之地震計基礎の振動}

1994年 8月に地表のM T を測定した。测定波形のスペ クトル解析はF F Tで行ったが、その時間刻みは $1 / 100$ 秒、 解析時間は約 14 0秒で、1000HammingWindowを標準と

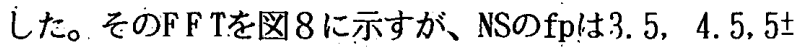

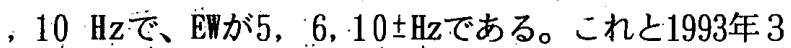
月に測定済みの基礎上の測定波形を用いて 3 成分のスペ クトル比を求め、図9に示す。スペクトル比のピークは

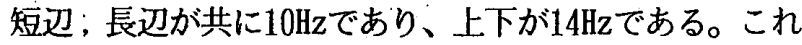
らは自由振動のfp之対応している。短边，長辺における $5 \mathrm{~Hz}$ 前後の鋭い谷は図8に示した地表いおけるMTのス ペクトルのピークに対応する。

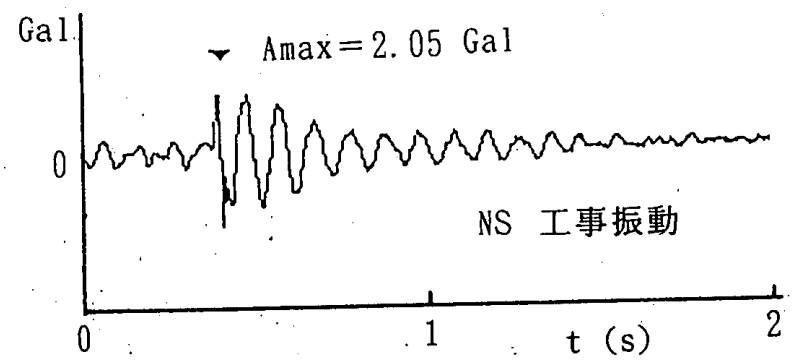

図5 常時徽動測定時の工事による基礎短辺の自由振動

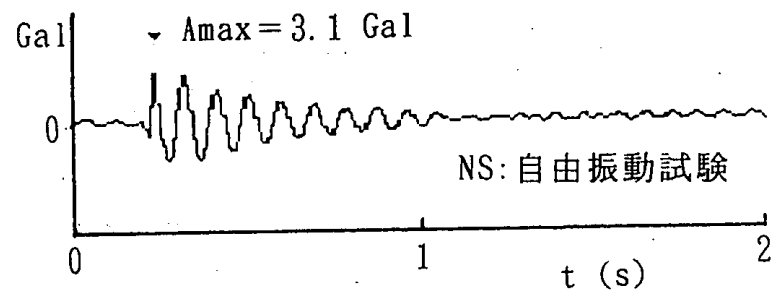

図6 基礎の自由振動波形例（短讱方向）

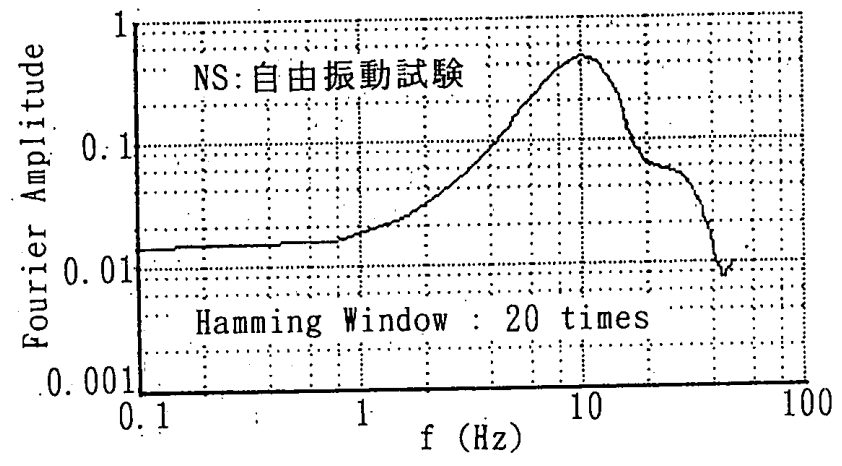

図7 自由振動波形のフーリェスペクトル（短辺方向）
表 1 気象台建物・基礎・地盤のfpとh

\begin{tabular}{|c|c|c|c|c|c|c|}
\hline & \multicolumn{2}{|c|}{ 短辺 } & \multicolumn{2}{|c|}{ 長 辺 } & \multirow{2}{*}{$\begin{array}{l}\text { 上下 } \\
\mathrm{fp}(\mathrm{Hz})\end{array}$} \\
\hline & & $\mathrm{fp}(\mathrm{Hz})$ & $h(x)$ & $\mathrm{fp}(\mathrm{Hz})$ & $h(x)$ & \\
\hline 基 & $M T=1$ & 10 & 4.8 & 10 & - & $14-15$ \\
\hline 礎 & $\mathrm{FV}^{* 2}$ & 10 & 4. 4 & 10 & 7 & 15 \\
\hline 建 & 西棟西 & $4 / 7$ & 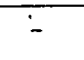 & $4 / 6-8$ & - & - \\
\hline \multirow[t]{2}{*}{ 物 } & 西棟東 & 4 & - & 4 & - & - \\
\hline & 東棟中 & 4 & $:-$ & 4 & - & - \\
\hline 地 & 盤 & $4.5,5.6$ & - & $.5,6,10$ & - & - \\
\hline 崖 & Sp比 & $\begin{array}{r}3.5,4.5 \\
5 \pm .10\end{array}$ & - & $5,6,10$ & - & 10.13 \\
\hline
\end{tabular}

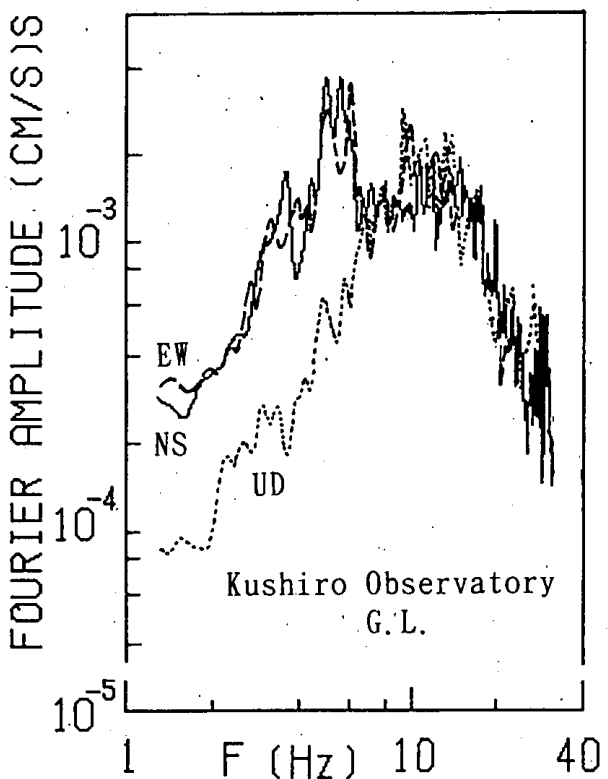

図8 地表における常時微動のフーリェスペクトル

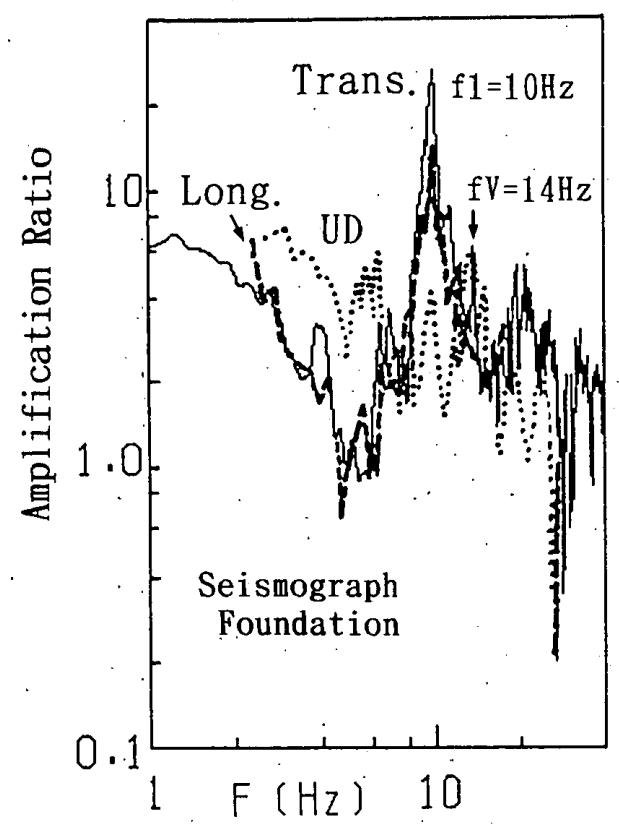

図9基礎上/地表のスペクトル比 


\section{3 地表と建物屋上の振動}

測定の日時は異なるが、地表と建物屋上の常時微動測 定記録からスペクトル比を求め、西棟について図10a)b)

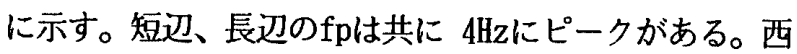
棟西は 6-8Hzに中程度のピークがある。図10c) も巨視的 には類似の傾向である。西棟短辺方向の約 $4 \mathrm{~Hz}$ は文献7） 〜9)とも整合性があり、2 階建て建物の 1 次固有振動数 と考えられる（表 1)。共通的に見られる4.5-5Hzの鋭 い谷は地表のピーク振動数にほぼ対応する。これは基礎 上のスペクトル比とも共通するものである。しかし、長 刃方向は $5.6 \mathrm{~Hz}^{7)}$ となっているので、この点は一致しな い。そこで、別の時間帯について分析したところ、傾向 はほぼ同一であった。

更に、その他の時間帯を調べたところ、微小地震かと 思われる記録部分があったので、そのスペクトル比を図 11に示す。同図は屋上のみ比較的振幅が大きな波形であ る。この図によれば、約 $4 \mathrm{~Hz}-6 \mathrm{~Hz}$ のピークは図10と変ら ないが、8Hz-12Hzの成分が大きくなっており、低振動数
成分が大である。特に、東棟の短、長牣は $9 \mathrm{H} z$ と $12 \mathrm{~Hz}$ の 成分が大きく、西棟西の短辺は12Hzが大である。この事 から、10Hzに近い振動数領域の振動特性は複雑であるこ とが分る。

\section{§4 強震記録の振動数特性}

4.1 ピーク振動数の変化

87型地震計とSHAC強震計の本震と余震の各記録につき スペクトルのピーク振動数fpの性状を調べた。それらの 結果と他の測定・解析の結果につき、之りあえず容易に 比較検討できる範囲について以下に示す。

\section{1）87型地震計}

87型地震計の記録の中からMが発表されているものに ついてFFTを求め、N153Eのスペクトルを図12に示す。 同図によれば、加速度レベルの小さい1月19日の余震 4.8)では最大加速度Amaxが15Galで、8-9Hzのスペクト ル振幅が最大である。これはM Tの $10 \mathrm{~Hz}$ と対応している。 2月 4 日の余震(H5.2)ではAmaxが87Galで、fpは約 7Hz
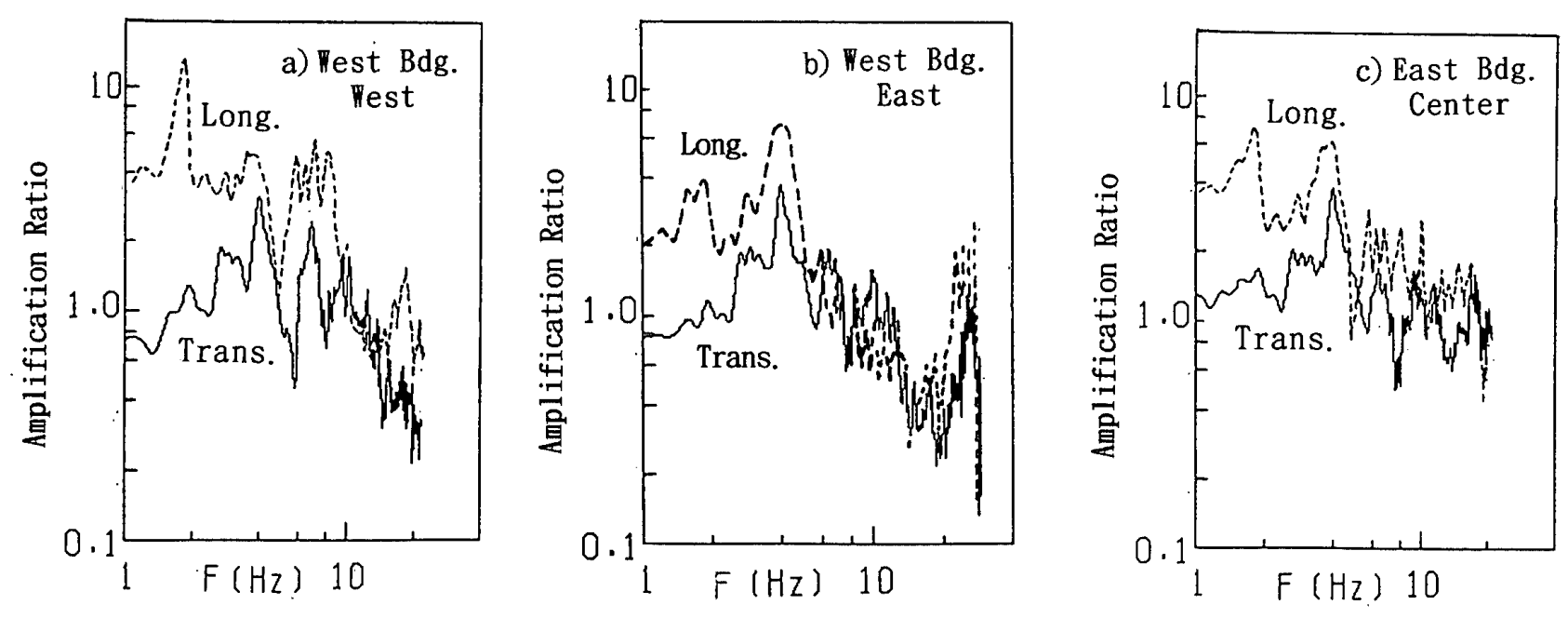

図10 屋上/地表のスペクトル比
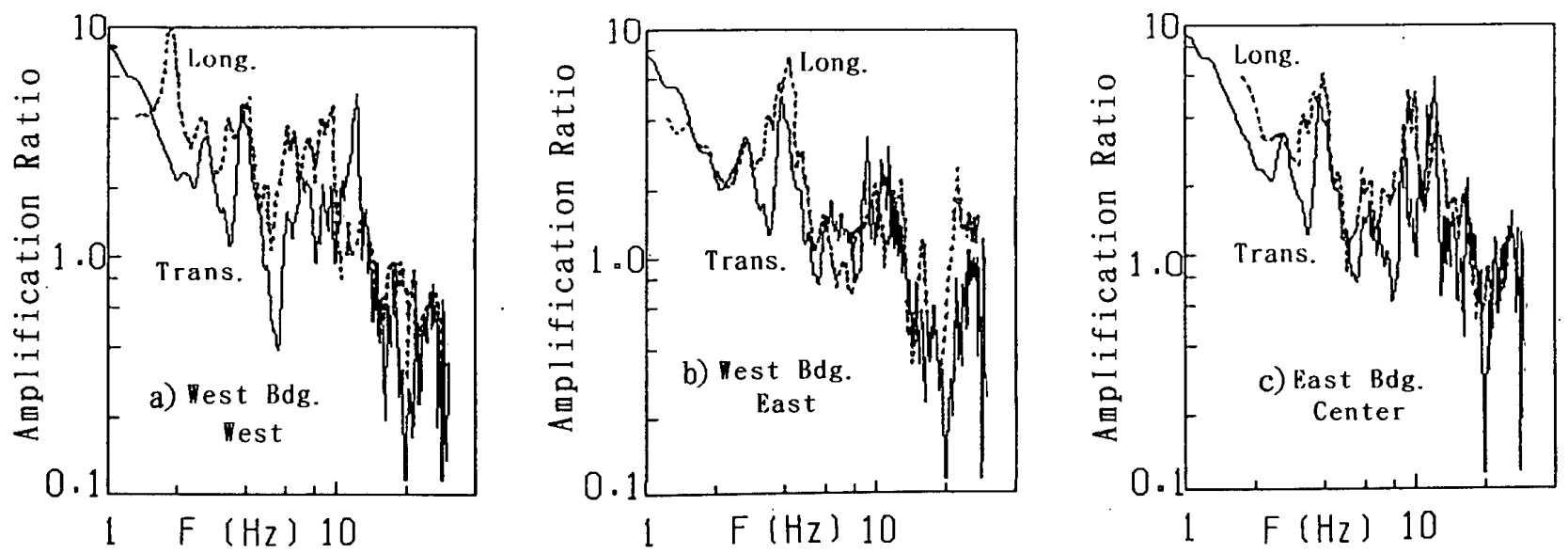

図11 屋上における大振幅微動のスペクトル比 


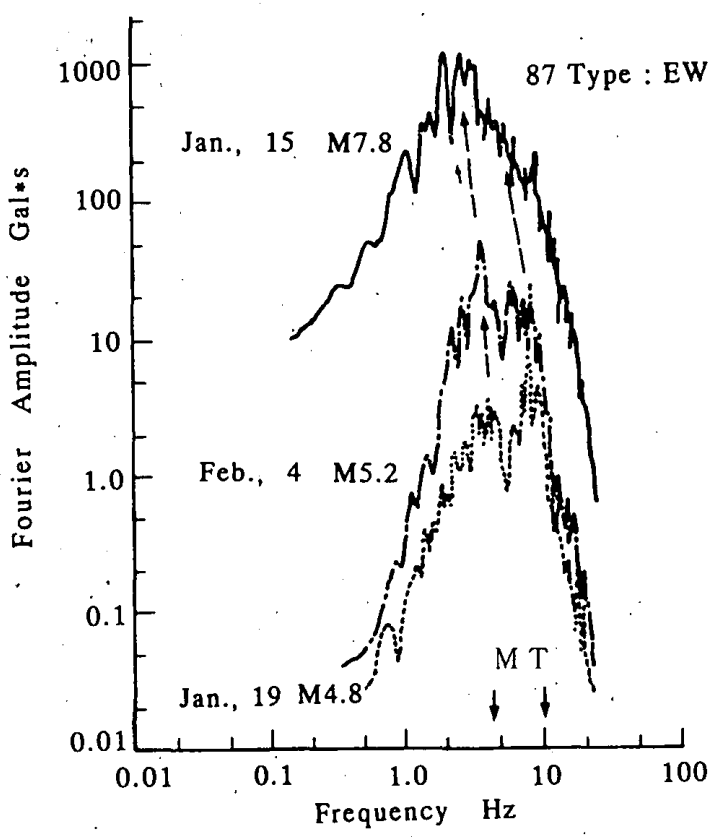

図12 87型地震計による本震、余震のF F Tとfpの変化

であり、その他にある $3-4 \mathrm{~Hz}$ のスペクトル振幅が幾分大 となる。本震では約 $2 \mathrm{~Hz}$ 弱のスペクトル振幅が最大で、 小・中加速度の余震で目立つ10Hzに近いスペクトル振幅 はそれほど目立たず、約 5 または $6 \mathrm{H} z の$ 並のピークに変 化している。

この事実を別の形でいえば、小加速度の地震では基礎 のスウェイ・ロッキングに起因する約 $10 \mathrm{~Hz}$ の成分が大き く影響するが、加速度レベルが大となるとその成分の影 響は相対的に小さくなる。この傾向は文献15)16)からも 読み取れる。

このfpの変化についてAmaxとの関係を求め、図13に示 す。この図で振動数に幅を与えたのは、スペクトルのど のピークにつながるか不明確な場合があるので、ある幅 をもったfpを求めたことによる。図中の左側はMTによ るfpの值である。この図を全体的にみると、明らかにAm axに対してfpが小さくなる傾向を示す。

文献1 5 )は87型の既往强震記録について水平 2 次元の 合成スペク、トルを求めたものであるが、そのピークも同 様に作図して図14に示す。図中の星印はMTによるfpの 例で、4.5 5.0 Hzが各種の測定で得られている。同図 によれば、基礎のfpは疑似速度応答スペクトルPS Vのレ ベルが低い範囲内では10Hzに近づく。また、本震では 5 Hzとなる。MTによる基礎のfpは共に $10 \mathrm{~Hz}$ であるが、そ の減衰定数は短辺が $4.5 \%$, 長辺が 7\%なので、その影 響が 2 次元合成スペクトルに反映されて図13之幾分異な る可能性が考えられる。しかし、結果的には図13と一致 する傾向である。これらの事から、大加速度によって基 礎周りの土の塑牲的な挙動が発生したであろうと想像さ れる。

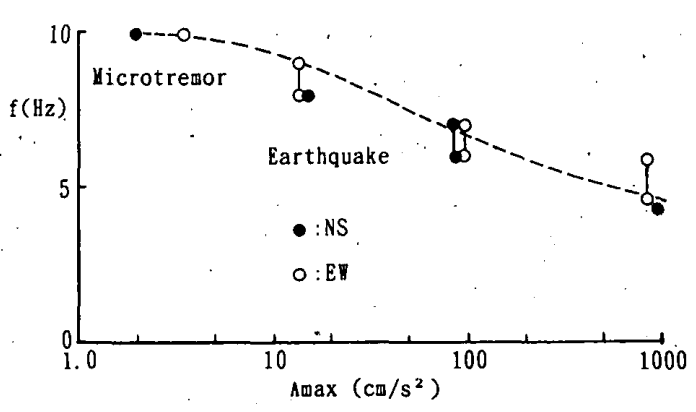

図13 87型地震計記録によるfpのAmax依存性

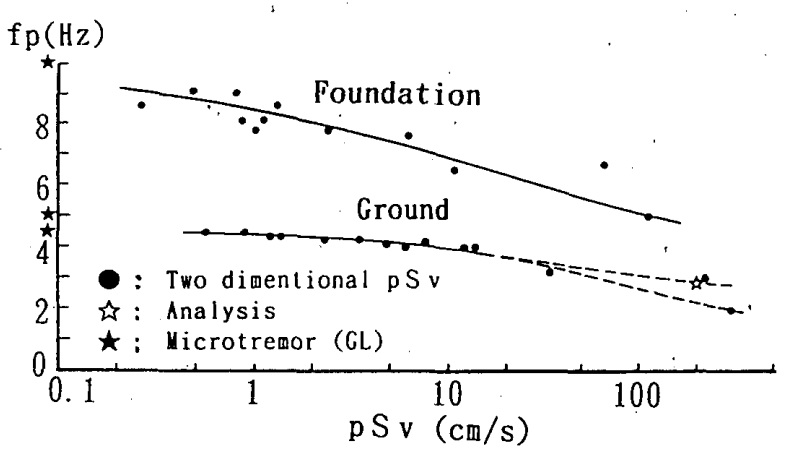

図14 87型地震計記録の水平 2 次元P S Vのfp依存性

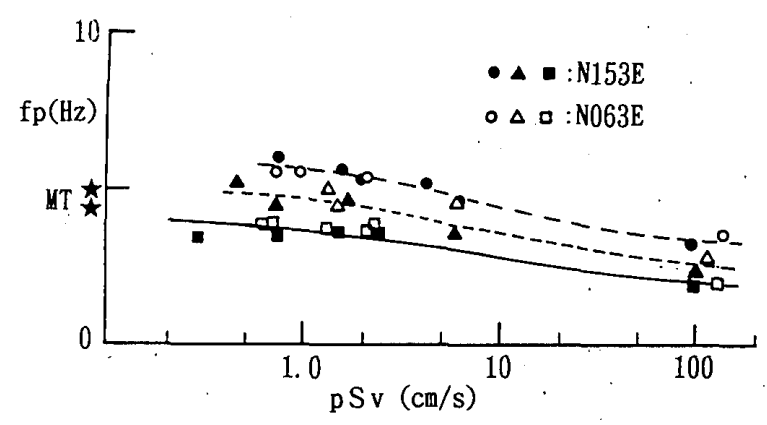

図15ＳWAC-MD型の記録によるP S VのVmax依存性

次に、地盤のfpについて調べる。図14によれば、PSV のレベルが低い範囲ではMTの $4.5 \mathrm{~Hz}$ 亿近づく。そして、 図14によれば、本震におけるfpは $2 \mathrm{~Hz} ま た は 3 \mathrm{H} \mathrm{zである。}$ 文献13)によれば本震で2.9Hzとあり、図12からは2.6 Hzが得られる。これらの事から、2.6〜 $3 \mathrm{~Hz}$ は表層地盤 の塑牲化によるもの之考えられる。従って、2 Hzの成分 の性質が問題点として残るが、文献12)による建物の弾 塑性応答の結果が2 H zに近づくこあるが、その影響もあ ると考えられる。この文献12)は87型とSMACのスペクト 儿此を求め、それを目標として地盤と構造物の非線形解 析の結果を一致させようとしたものである。但し、 $2 \mathrm{~Hz}$ 近く以上の高い振動成分についてはスペクトル比のレベ ルを説明できないとされている。

\section{2) SUAC强震計}

気象台構内の地表で記録されたSMAC強震計の本震と余 震の記録について得られている PSV'い のレベルとその fpの関係を求め、図15に示す。この図は地表の比較的軟 
弱な地層のfpと考えられる $4 \sim 6 \mathrm{~Hz}$ の成分について調べ たものである。更に地中地震計による強震記録のfpは文 献1 7 ) よりN153Eが 4 . $5 \mathrm{~Hz}$, N63Eが4. $3 \mathrm{~Hz}$ と得られている。 これは文献1 8)のMTの測定結果による4.5Hzとも対応 する。そこで、ここでは図15に実線で示したfpの延長線 はM Tのfp=4.5Hzに到達するものと判断する。また、 文献1 9 )によれば、J M 0のMTによる水平と上下のスペ クトル比 / Vは3. $3 \mathrm{~Hz}$ と $5 \mathrm{~Hz}$ 亿同程度のピークをもつ。 ここに、H:水平、 $\mathrm{V}:$ 上下の各スペクトルであり、文献20 ）によれば、H／Vのピークは表層地盤の水平成分の振動 特性をよく表すとある。

一般に、Mが大となるか、または大加速度になると、 軟弱な表層の塑牲化のみならず、長周期成分が伝播した り、更にその下の地層も刺激される。しかし、文献2 1) で示されている様に、ごく表首の地盤の非線形性が主因 との考え方がこの本震の様な大加速度記録について考慮 すべきであろう。このfpの低下に関わる分析は、地中の 强震観剆を含めて明確化されつつある ${ }^{131171221 。 4.1}$ の1)項でふれたように、文献 13 )では小地震の $\mathrm{fp}=4 \mathrm{~Hz}$ が、本震では2.9Hzになったと推定されている。この2. $9 \mathrm{H} z$ は図15に示した 3 本の線の中央の点線に近く、MT の $5 \mathrm{H} z$ に結びつく傾向である。図15の下段の実線は、M Tで4. 5Hzであったものが本震では $2 \mathrm{~Hz}$ となっている。 この值については後で吟味する。

\section{3）地艋㽢性の低下}

地盤のみの塑性化に止まらず、地震計基礎はその応答 による応力が加わって基礎周边の地盤がより多く塑牲化 し、fpが低下したものと判断できよう。一方、建物の重 量による地盤剛性の増加も文献12)で分析されているよ うに、建物直下のVsが増加する要因もある。

図13，14から分かる様に、本震時の基礎のfpは約半分 の5 H zに低下している。この主たる原因が地盤の塑牲化 にあるとすれば、基礎周りの地盤の剪断波速度Vsもこれ に近く低下したことになる。これは図15から推定される 低下より更に低いVsをもたらす可能性をもつ。

文献13)によれば、GL-1.9mから-8.15mにあるシルト 質火山灰層の剪断昰度 $\gamma$ は0.3\%に及ぶもので、これが fpの低下の主因をなしていると理解される。また、地震 計基礎が接している地層の $\gamma$ は約 $0.05 \%$ とある。しかし、 一般に、基礎周辺の土は工事の際に摫乱されるし、Vsは 70-80m程度となる例が多いので、ここでも基礎側面のVs が100m/sを越えることは少ないと考えられる。文献3）に よれぱ、MTによるfpから基礎の側面がなく、基礎底面 の応力は㓮板分布と仮定して得られた値はVs=72m/sとさ れている。実際には埋土と松杭の效果を含むので、強震 時におけるVsはこれより更に小さくなるはずである。文

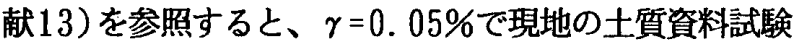
から得られた $G / G_{0}$ は約70\%に低下しているので、これ
だけでもVs ける基礎周りの応力集中部分のVsは部分的に更に小さく なった可能性がある。

\section{2 ピーク振動数の低下に伴う淢衰性}

上述のような87型の記録のスペクトル分析から、加速 度レベルの増大に伴うfpの低振動数への移行之鋭さが消 失するのは、地盤の非線形性、特に基礎周りの歪みの増 大によるものと考えられる。

これに対して、減衰定数hも地盤の歪み $\gamma$ に依存する 增大が当然ある。近年における土の動的室内試験で明ら かにされた結果によれば、大歪み領域における $\mathrm{h} は 20 \sim$ $30 \%$ の例が多く、この様な h の増加により図12の本震の スペクトルにおいてピークの鋭さが消失する結果をもた らしていると考えられる。

\section{5 気象台の位置する丘の増愊特性}

気象台 (JM0)の地表面は標高約 $31.3 \mathrm{~m}$ で、北側崖の下 部道路面と約 $28.6 \mathrm{~m}$ の高低差がある。崖下の道路脇に位 置するつたや旅館(TYR)のGLにおけるM Tの測定を行い、 J M 0のGLの測定值と比較する。T Y R J J M 0のスペクトル 比を求め、図16に示す。

この図によれば、水平と上下とも約 $10 \mathrm{~Hz}$ 以上でなだら かで大きなピークをもち、スペクトル比の最大値は50前 後である。10Hz以上の高い振動数の議論には限度がある ので除くと、NSが5-6Hz， 4.5Hz前後，3.5Hz，E蚆5、 $6 \mathrm{~Hz}$ 等に水平成分のピークが目立つ（表1)。J M 0のM T も考慮すれば、地表のfpとして4. $5 \mathrm{~Hz}$ と 5Hzが注目され る。なお、この湘定時刻は一日のずれがあるので、低振 動数のスペクトルのレベルに関してはこれを認識してお く必要がある。

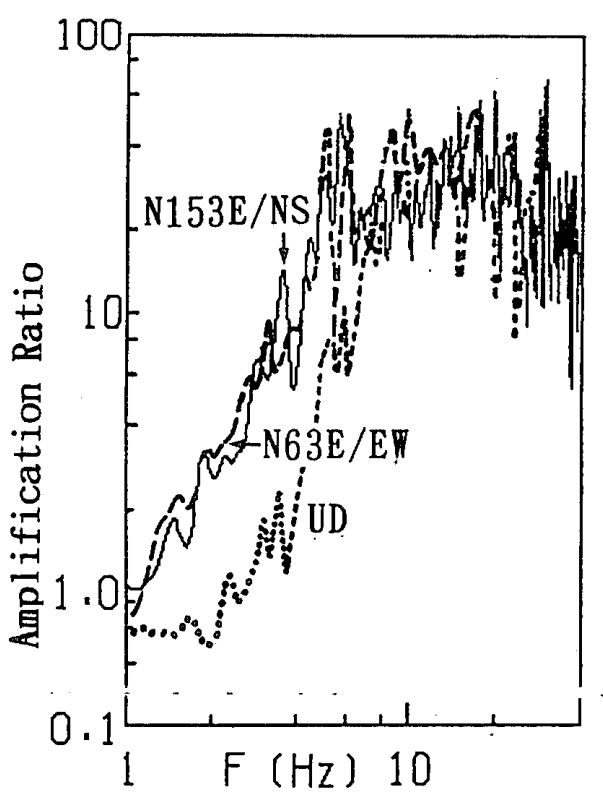

図16＼cjkstart崖下と気象台の常時微動スペクトル比 
T Y Rの 1 階における建物基礎上に設置した地震計によ り、1994年 8月25日10時25分の地震 (145.2)の加速度記録 が得られた。その記録を図17に示し、水平 2 成分のF F T を図18に示す。AmaxはNSが6. 6Gal，EWが9.3Galである。

一方、同一の地震についてJ萌0の表層地盤で観測され た強震記録 (7)によれば、GL-22mではN153Eが 9.2Gal, .N63Eが7.5.Galである。TYRにおける第三紀（浦幌層 群）は同一地層ながら、レベルは6唋り低く、かつ自由 地表面であるが、Amaxはかなり近い值である。fpはT Y R のNSが6 H zであるのに対して、J M 0のN153Eは前述した 様に $4.5 \mathrm{~Hz}$ で、Eが同じく $4.5 \mathrm{~Hz}$ と $4.3 \mathrm{~Hz}$ である。J M 0 のGL-1.95mにおけるAmaxはGL-22mの6.3-9.0倍である がこれは $4.5 \mathrm{~Hz} \sim 6 \mathrm{~Hz}$ といった比較的高い振動数をも つ入力に刺激されてJ M0の丘が庍答し、増幅率が大とな ったものと理解される。地中からのスペクトル比や崖下 からの増幅に関する詳細な議論は今後に期待される。

\section{\$6 他の梖定、解折を含めた総合的評価}

前章までに筆者らが行ってきた気象台の敷地地盤、地 震計基磷、建物の振動特性を中心に述べてきた。他にも 多数の測定、研究がなされているので、これらと比較検 討して、前項までの結果を分析する。この試みは、文献 23 )である程度なされているが、ここでは地盤、地震計 基礎、建物を中心にその他の諸研究も含めて総合的に評 価する。

現時点までの各種研究による振動数を一覧して表 2 に 示す。なお、研究者によって複数の馀文を出されている もののうち、一部を省略したものもある。また、上下と 水平のスペクトル比の $\mathrm{H} / \mathrm{V}$ が求められているので、これ らを一部活用させて頂いた ${ }^{19124)}$ 。以下、表 2 を中心に
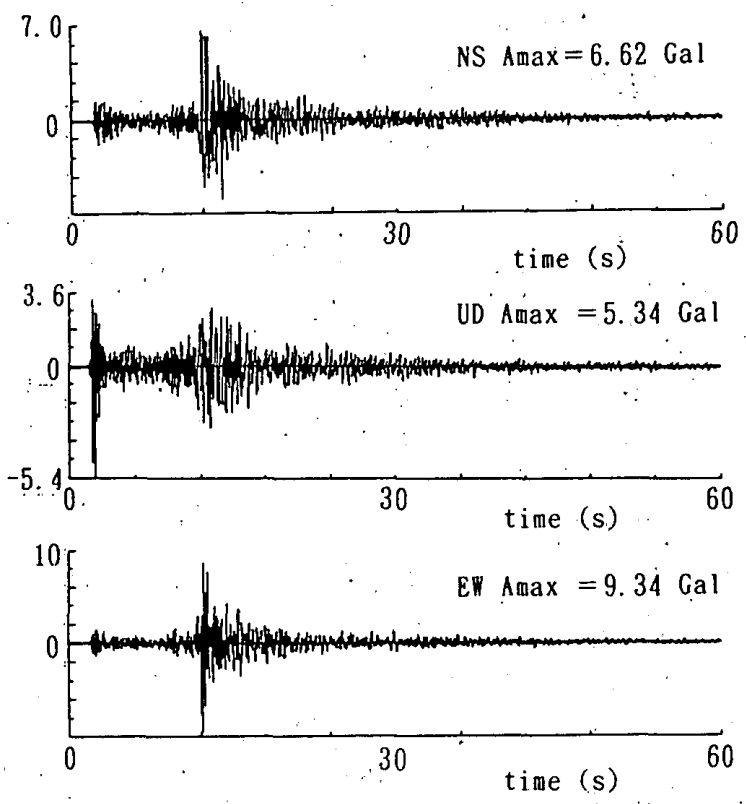

図17 1994年 8月25日の地震によるT Y Rの加速度波形

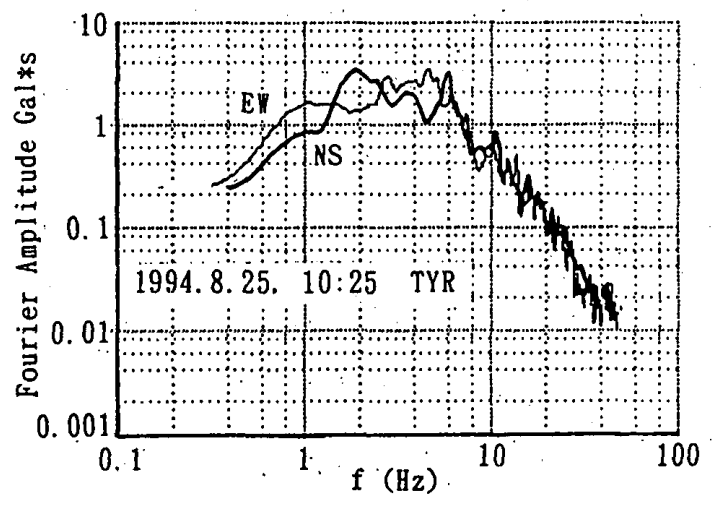

図18１994年 8月25日の地震によるT Y RのF F T

表 2 各種の研究結果による気象台の振動数一覧

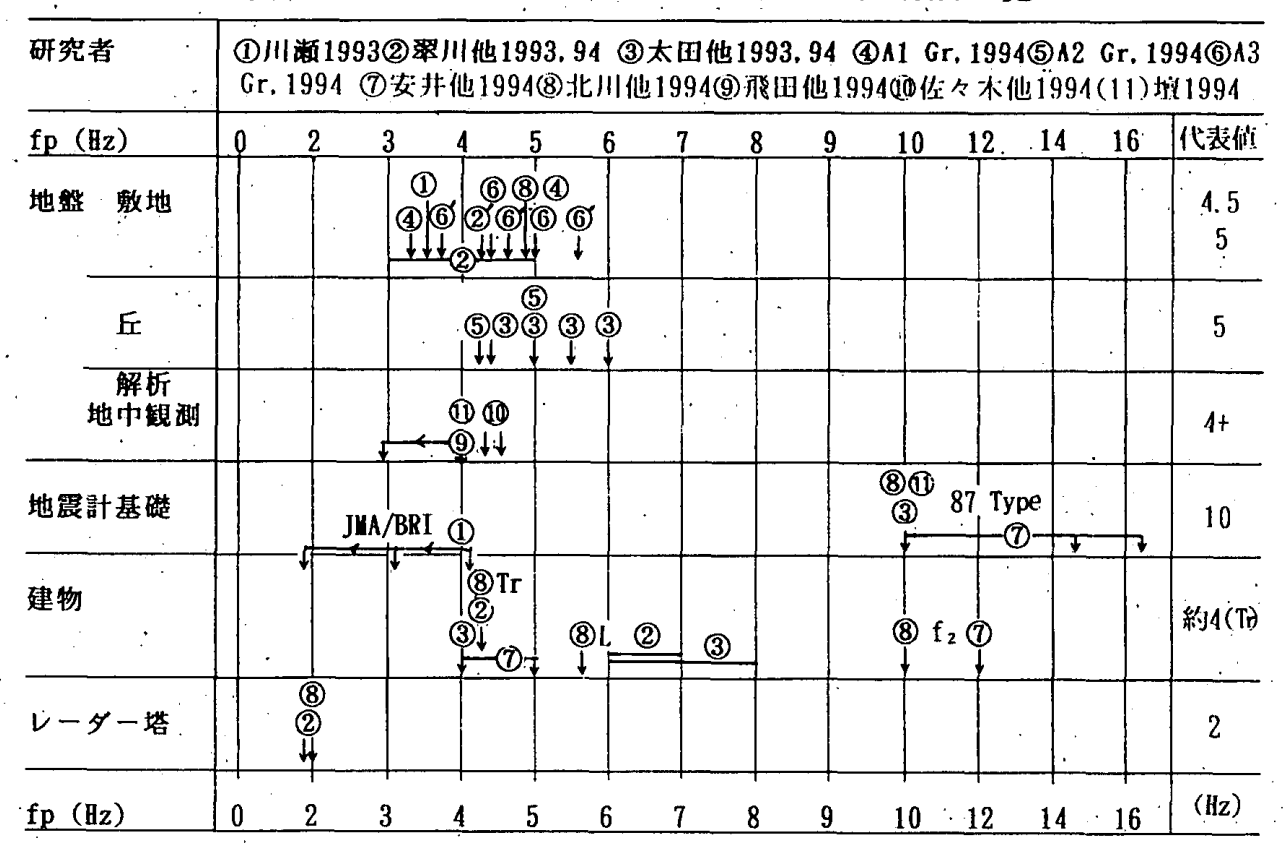




\section{その内容について述べる。}

\section{1）気象台の教地地船}

表 2 において、JM0敷地の表層地盤のfpは約 $3 \mathrm{H}$ zから $6 \mathrm{H} z$ 弱に亘って分布する。また、敷地内 $\mathrm{NMT}$ のスペク トルと、敷地外の岩盤における測定作 このスペクトル比 は $4 \mathrm{H} z$ 強と $5 \mathrm{H} z$ 前後に多く集まって.、る。敷地内の地中 地震観測と支持岩盤からの地震応答解析によれぱ、弾性 的には4-4.5H z にわたるfpである。これらを総合して、 本論では $4.5 \mathrm{~Hz}$ と $5.0 \mathrm{~Hz}$ J M 0 敷地の代表的な弾性範囲 のfpと考え、表2に示す。

\section{2） 87 型地震計基礎}

87型地震計基礎について、MTによる水平方向の $\mathrm{f} p=$ 10Hzは文献7) 9), 文献12)において、建物の 2 次固有振 動数に刺激された可能性が述べられているが、これは文 献10)11)21)で否定的であり、10Hzとみてよいと判断さ 几る。本震時にはこのfpは低下するが、その程度は図13、 図14より約半分の $5 \mathrm{H} \mathrm{z}$ となる。これを解析的に評価しよ うとすると、14.5Hzないし16.5Hzとなり、文献?つ $10 \mathrm{~Hz}$ に至らしめるには埋土の効果を無視する必要があるとし ているい'。従って、この解析的評価に関しては基礎側 面の土と、強度が低下したであうj杭の効果を改めて調 べ直す必要がある。

3）気象台の建物等

建物は地震計室のある西棟（旧棟）のみについて述べ ると、短辺の 1次は約 $4 \mathrm{~Hz}$ 之判断して良いであろう（表 2）。一般に、低層建物の短辺 2 次はスウェイ・ロッキ ングが刺激されるモードであるが、 $10 \mathrm{~Hz}^{1{ }^{11}}$ と $12 \mathrm{~Hz}^{\top}$ の 結果が報告されている。図10で約10Hzのスペクトル比を みると、約 $4 \mathrm{~Hz}$ zの 1 次に対して数分の 1 であり、スペク トル比の值は 1 に近いので、前述した様な地震計基礎を 刺敫する勢力はないかと考えられる。更に、図10と図 9 の10Hzの値を比較すれば、屋上/地表のスペクトル比は 基礎上/地表の約20分の 1である。また、文献11)によ れば、建物の基礎が地震計基礎を拘束するという条件の 解析を通じて、地震計基礎は建物とは独立的であること が明らかにされている。これらが「地震計基礎の10Hzは 建物 2 次の影響か?」の考え方を否定する直接的な論拠 といえる。なお、微小地震かとも考えられる記録のスペ クトル比によれば、前述のように12Hzの成分が西棟西に 見られるが、西棟東では大きくないので、全体を支配す るほどではないようである。

これらは常時微動測定や微小振幅の記録であることか ら、ある程度のバラツキは覚悟せざるを得ず、正確には より詳細なMTの測定や、起振機による振動実験の結果 を期待せざるを得ない。

一方、SMACと87型の本震記録について、スペクトル比 を求めた文献1）25)によれば、約 2Hzにピークがある。 これは建物の塑性的応答の影響を地震計基礎も受けたと
いう文献12）の考え方が有力視される。この点について は今後の確認的研究が望まれる。

4) レーダー塔

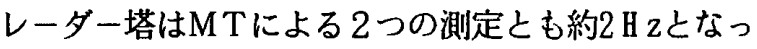
ているので、その点については特に問題はない。これに 関連して文献12)15)では、レーダー塔の渡り廊下が本震 時に衝笑した可能性を述べている。本論では、この可能 性は無いものと考える。その理由は、表層地盤、地震計 基礎、及び建物の塑性応答が共通的に認識されている現 状下で、レーダー塔のみM $\mathrm{M}$ 个 $2 \mathrm{H}$ zが非線形性を示さな いことは常識的に考えられないからである。また、文献 23)でも87型/SHACの非定常スペクトル比の結果から、 レーダー塔の関与を否定している。

そして、本震で $\mathrm{H}$ z の大きなパワーが発生した原因は、 文献1 3 )においてN63Eでは支持岩盤に約 $2 \mathrm{H} \mathrm{z}$ 成分が含 まれている様であることと、87型では前項3)で述べた様 に、建物の塑性的応答の影響が加わった可能性がある。

以上の諸点を考慮して、現時点で考えられる代表的な 弾性領域のfpを表 2 の右側に示す。

\section{$\S 7$ 結び}

釧路気象台で記録された87型地震計とSHAC強震計の記 録について、地震計用基礎の固有振動、気象台建物と表 層地盤の振動特性、並びに北側崖下からの増幅について 分析した結果をまとめた。また、他の関連研究と比較検 討し、現時点で言及できる範囲の卓越振動数を明確化し た。その要点は次の通りである。

1)常時微動による地表と地震計用基礎とのスペクトル比 は、水平 2 成分が共に $10 \mathrm{~Hz}$ の鋭いピークをもち、その レベルは約20である。また、上下成分は14〜15Hzのピ ークをもつ。

2)87型の強震記録では、Amaxの小さい記録で10Hzに近い fpで鋭いピークを持つものの、Amaxのレベルが大きく なるとfpは低下し、本震では約 $5 \mathrm{~Hz}$ となる傾向が見ら れ、スペクトルのピークの鋭さが低下する。

3)気象台の地表における常時微動のfpは主として $4.5 \mathrm{~Hz}$ と、 $5 \mathrm{~Hz}$ にも刺激される成分がある。但し、常時微動 特有のバラツキをもつものである。

4)気象台の地表之西棟屋上における常時微動のスペクト

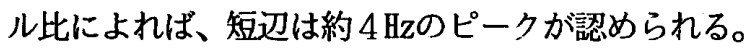
長匄のfpもそれに近いが、測定によって幾分ばらつく。 地表に対するスペクトル比のレベルは約 $4 \mathrm{H} \mathrm{zが} 4 \sim 6$ で、地震計基礎のそれの数分の 1 である。また、約 10 $\mathrm{Hz}$ 付近のスペクトル比のレベルは 1 前後で、1)項に示 しけ20倍のレベルとは隔たりが大きいことから、地震 計基礎を大きく刺激している可能性は少ない。

5)気象台北側の崖下に位置する古第三紀層の地表と、気 象台地表の常時微動のスペクトル比によ机ば、fpは3. 
$5 ， 4.5 ， 5 ， 6 \mathrm{~Hz}$ が目立つ。これらは気象台の表層地 盤における $\mathrm{fp}$ と概ね対応している。また、10Hz程度の 倍率も大きい。

6)多数の研究結果を整理して筆者らの結果と比較検討し、 気像台の地盤、地震計基礎、仃舎建物、レーダー塔の fpの值について代表的な値を示した。

以上が他の研究も参照した上で本論において明確化し た諸点である。これらを踏まえて、今後、87型地震計基 礎の非線形性を詳細に分析したい。

また、残る問題点として次の事項が指摘でき、これら は今後の研究に期待される。

1）地盤－建物一地震計基礎の弾塑性応答に関するより詳 細なつめが必要で、内容的には全体系と87型地震計基 礎の 2 つに分けられるであろう。建物は記録によって $10 \mathrm{~Hz}$ 前後の振動が刺激されることもある。

2)建物長辺方向のfpの測定、解析は短扨に比して少なく、 値の幅もあるので、より明確化される事が望ましい。 このため、より詳細な実験研究を実施できる機会を生 かせることが出来れば幸いと考える。

気象台の常時微動測定につき、関係者に種々ご配慮を 賜った。また、有用な87型地震計の記録を広くご提供下 さっている気象庁に敬意を表します。スペクトル解析等 については足利工業大学の石橋直樹君に、原稿作成には 同飛田恭彦君に協力頂いた。ここに厚く感謝の意を表し ます。

\section{参考文献}

1）翠川三郎、松岡昌志 : 1993年釧路沖地震におりる釧 路市内の地震動強さ、その 3、日本建築学会大会学術 講演梗概集, B, pp. 5-6, 1993.9

2）鹿島俊英、北川良和 : 釧路気象台の強震記録の特性、 日本建築学会大会講演梗概集, B, pp. 11-12, 1993.9

3) 太田外氣晴、友野章、山中智裕 : 釧路気象台87型地 震計基礎の振動特性、日本建築学会大会学術講演梗概 集, B, pp. 13-14, 1993. 9

4)川瀬博 : 北海道内の各地気象台における強震動特性、 日本建築学会構造系論文報告集、No. 459, pp. 57-64, 1994.5

5) 片岡俊一 : 釧路気象台周辺の常時微動特性亡建物被 害、第21回地盤震動シンポジュウム、日本建築学会、 pp. 43-48, 1993. 11

6) 瀬尾和大（研究代表者）：地震時の地盤震動特性評 価のための微動の活用に関する研究、平成 5 年度科研 成果報告、平成 6 年 3 月

7) 北川良和、大川出、鹿島俊英、小山信、横田崇 : 釧 路地方気象台建物之敷地地盤の振動特性、その 1、日 本建築学会大会学術講演梗概集、pp. 437-438, 1994.9 8) 北川良和、大川出、鹿島俊英、小山信、横田崇 : 釧 路地方気象台建物之敷地地盤の振動特性、その 2 , 日 本建築学会大会学術講演梗概集、pp. 439-440, 1994.9 9) 北川良和、大川出、鹿島俊英、小山信、横田崇 : 釧 路地方気象台建物と敷地地盤の振動特性、その 3 , 日 本建築学会大会学術講演梗概集、pp. 441-442, 1994.9 10）太田外氣晴 : 釧路気象台における強震動之地盤・構 造物の振動特性、1993年釗路沖地震に関する総合シン ポジュウム、日本建築学会、pp. 127-132, 1994. 12

11）安井䗙、高野真一郎：釗路気象台建物・強震計基礎 の相互作用の影響、1993年釧路沖地震に関する総合シ ンポジュウム、日本建築学会、pp. 127-132, 1994.12

12) 壇一男 : 釧路地方気象台建物の非線形相互作用解析 1993年釧路沖地震に関する総合シンポジュウム、日本 建築学会、pp. 85-92, 1994. 12

13）飛田潤、杉村義広 : 釧路地方気象台および釧路市内 の地震動特性における表層地盤の影響、1993年釧路沖 地震に関する総合シンポジュウム、日本建築学会, pp.

$59-64,1994.12$

14）北海道建築士会釗路市支部 : 釧路市の地盤、1982年

15）翠川三郎、松岡昌志 : 釧路気象台構内で観測された 強震記録のスペクトル特性、日本建築学会大会学術講 演梗概集, B, pp. 433-434, 1994. 9

16）建設省建築研究所: 釧路気象台敷地内地盤調查結果、 地震工学新興会ニュース、No. $136, p p .56-60$, 平成 6 年 5 月

17）佐々木透、丹羽正徳：釧路気象台における強震観測、 日本地震学会講演予稿集、No. 2, p. 236, 1994. 10

18）松岡昌志、翠川三郎：1993年釧路沖地震における釧 路市内の地震動強さ、その 2、日本建築学会大会学術 講演梗概集, B, pp. 3-4, 1993.9

19）山中浩明(A-1長周期グループ)：釧路市内の広域を 対象とした長周期微動の同時観湘、平成 5 年度科学研 究費補助金 [試験研究 (B 1) (1) ] , pp. 33-54, 平成 6 年 3 月

20）中村豊、上野真 : 地表面震動の上下成分と水平成分 を利用した表層地盤特性推定の試み、第 7 回日本地震 工学シンポジュウム、pp. 265-270, 1986年12月

21) 翠川三郎 : 強震時にみられる地盤特性の非線形性、 地震学会、地震、第2 輯、第46巻、pp. 207-216, 1993 .

22 ) 鹿島俊英、小山信 : 釧路気象台庁舎の振動特性、19 93年釧路沖地震に関する総合シンポジュウム、日本建 築学会、pp. 139-142, 1994. 12

23) 福和伸夫 : 相互作用をどのように理解するか、1993 年釧路沖地震に関する総合シンポジュウム、日本建築 学会、pp. 139-142, 1994. 12

24)片岡俊一 $(\mathrm{A}-3$ グループ : 釧路気象台構内での高密 度の微動同時観測、平成 5 年度科学研究費補助金 [試 験研究(B) (1)], pp. 33-54, 平成 6 年 3 月

25)川瀬博 : 1993年釧路沖地震における釧路気象台の非 線形応答特性、地球惑星科学関連学会1994年合同大会 予稿集、pp. 332, 1994. 3

（1995年 2 月10日原稿受理，1995年 4 月25日採用決定） 